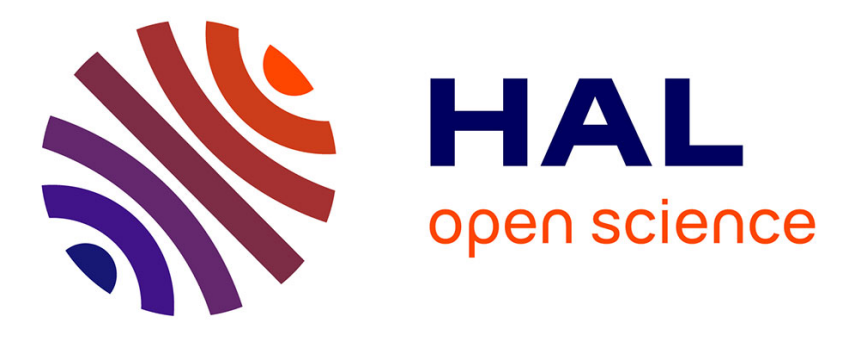

\title{
Homologous yeast lipases/acyltransferases exhibit remarkable cold-active properties.
}

Pisey M Neang, Maeva Subileau, Véronique Perrier, Eric Dubreucq

\section{To cite this version:}

Pisey M Neang, Maeva Subileau, Véronique Perrier, Eric Dubreucq. Homologous yeast lipases/acyltransferases exhibit remarkable cold-active properties.. Applied Microbiology and Biotechnology, 2014, 98 (21), 10 p. 10.1007/s00253-014-5776-6 . hal-01189940

\section{HAL Id: hal-01189940 \\ https://hal.science/hal-01189940}

Submitted on 1 Sep 2015

HAL is a multi-disciplinary open access archive for the deposit and dissemination of scientific research documents, whether they are published or not. The documents may come from teaching and research institutions in France or abroad, or from public or private research centers.
L'archive ouverte pluridisciplinaire HAL, est destinée au dépôt et à la diffusion de documents scientifiques de niveau recherche, publiés ou non, émanant des établissements d'enseignement et de recherche français ou étrangers, des laboratoires publics ou privés. 


\title{
Homologous yeast lipases/acyltransferases exhibit remarkable cold-active properties
}

\author{
Pisey M. Neang • Maeva Subileau • Véronique Perrier • \\ Eric Dubreucq
}

Received: 30 January 2014 / Revised: 10 April 2014 / Accepted: 12 April 2014

(C) Springer-Verlag Berlin Heidelberg 2014

\begin{abstract}
Lipases/acyltransferases catalyse acyltransfer to various nucleophiles preferentially to hydrolysis even in aqueous media with high thermodynamic activity of water $\left(a_{\mathrm{w}}\right.$ $>0.9$ ). Characterization of hydrolysis and acyltransfer activities in a large range of temperature $\left(5\right.$ to $\left.80{ }^{\circ} \mathrm{C}\right)$ of secreted recombinant homologous lipases of the Pseudozyma antarctica lipase A superfamily (CaLA) expressed in Pichia pastoris, enlighten the exceptional cold-activity of two remarkable lipases/acyltransferases: CpLIP2 from Candida parapsilosis and CtroL4 from Candida tropicalis. The activation energy of the reactions catalysed by CpLIP2 and CtroL4 was $18-23 \mathrm{~kJ} \mathrm{~mol}^{-1}$ for hydrolysis and less than $15 \mathrm{~kJ} \mathrm{~mol}^{-1}$ for transesterification between 5 and $35^{\circ} \mathrm{C}$, while it was respectively 43 and $47 \mathrm{~kJ} \mathrm{~mol}^{-1}$ with the thermostable CaLA. A remarkable consequence is the high rate of the reactions catalysed by CpLIP2 and CtroL4 at very low temperatures, with CpLIP2 displaying at $5{ }^{\circ} \mathrm{C} 65 \%$ of its alcoholysis activity and $45 \%$ of its hydrolysis activity at $30{ }^{\circ} \mathrm{C}$. These results suggest that, within the CaLA superfamily and its homologous subgroups, common structural determinants might allow both acyltransfer and cold-active properties. Such biocatalysts are of great interest for the efficient synthesis or functionalization of temperature-sensitive lipid derivatives, or more generally to lessen the environmental impact of biocatalytic processes.
\end{abstract}

\section{P. M. Neang}

Département de génie chimique et de génie biotechnologique,

Faculté de génie, Sherbrooke University, 2500, Boulevard de

l'Université, Sherbrooke, Québec J1K 2R1, Canada

M. Subileau $(\bowtie) \cdot$ V. Perrier $\cdot$ E. Dubreucq

Microbiological and Enzyme Biotechnology of Lipids and

Agropolymers, UMR IATE, Montpellier SupAgro, 2 Place Viala,

34060 Montpellier, Cedex 2, France

e-mail: subileau@supagro.inra.fr
Keywords Cold-active enzyme · Alcoholysis · Lipase/ acyltransferase $\cdot$ Pseudozyma antarctica lipase A $\cdot$ Candida parapsilosis $\cdot$ Candida tropicalis

\section{Introduction}

Lipases (EC 3.1.1.3) are ubiquitous enzymes that naturally catalyse hydrolysis of fats and oils into free fatty acids and glycerol. In addition to hydrolysis, they are able to catalyse condensation reactions such as esterification or acyltransfer reactions like alcoholysis. The diversity of their origins (plants, animals and microorganisms) ensures not only their natural availability but also their huge varieties of functional characteristics for applications in diverse sectors (Jaeger and Eggert 2002; Hills 2003; Hasan et al. 2006; Villeneuve 2007; Christopher et al. 2014). Because the presence of water in the reaction is generally favourable to hydrolysis, the use of lipases for synthesis reaction is mostly conducted in media with strict control of the $a_{\mathrm{w}}$ (in organic solvent or solvent-free conditions) in which enzyme stability is crucial (Adlercreutz 2013; Christopher et al. 2014). The development of such processes thus becomes quite challenging when two substrates with different polarity and solvent affinity are to be reacted (Villeneuve 2007). Besides, one of the most important characteristic for industrial enzyme development is their operational stability. Although it is generally considered that industrial applications require thermostable enzymes, heatlabile, cold-adapted lipases have been increasingly used in a wide range of applications, especially the detergents (cold washing), food industries (fermentation, cheese manufacture, meat tenderizing, lipid structuration), environmental bioremediations, biotransformation and molecular biology (Gerday et al. 2000; Joseph et al. 2008). Cold-active enzymes exhibit high catalytic activity at near-zero to room temperatures because of a higher flexibility and/or a local instability that allow 
the reduction of the free energy barrier of the transition state by destabilizing the structures bearing the active site or the whole molecule (decrease of activation enthalpy, increase conformational entropy) (Cavicchioli et al. 2002; Roca et al. 2007; Casanueva et al. 2010; Feller 2010; Struvay and Feller 2012). Cold-active lipases are thus of particular interest for the lipophilization and production of thermolabile compounds at high rates and for the economic benefits through energy saving: functioning in/during cold environments/season, minimizing undesirable higher temperature occurring-chemical reactions, avoiding the requirement of unnecessary heating steps and being rapidly and easily inactivated when required (Gerday et al. 2000; Joseph et al. 2008). These lipases are usually produced by psychrophilic microorganisms isolated from cold environments such as the Antarctic (Parra et al. 2008; Wang et al. 2012; Litantra et al. 2013), deep-sea sediments (Jeon et al. 2009) or other cold regions of the world (Zheng et al. 2011; Tanaka et al. 2012). In order to survive and proliferate in such extreme conditions, these microorganisms must synthesize naturally evolved enzymes exhibiting high activity at low temperature. Several studies have brought insights into protein structure and temperature adaptation relationships. It is generally admitted that a higher flexibility remains the main adaptive characteristic of psychrophilic enzymes compared to their meso- or thermophilic homologs. Within proteins families, different structural strategies exist to reach this structural specificity (Nielsen et al. 1999; Gianese et al. 2002; Siddiqui and Cavicchioli 2006; Joseph et al. 2008; Struvay and Feller 2012; Florczak et al. 2013). In literature, the major structural determinants described in cold-active enzymes are a decrease of the number of the ion pairs and salt bridges (reduced number of aspartic acid, glutamic acid and arginine residues), the charge-dipole interactions in $\alpha$-helices and side-chain contributions to the exposed surface, the apolar fraction of the buried surface and the aromatic-aromatic interactions, all consistent with a decrease of optimum temperatures (Arpigny et al. 1997; Smalås et al. 2000; Gianese et al. 2002; Joseph et al. 2008; Casanueva et al. 2010). These subtle structural characteristics are often localized close to the catalytic site or the specificity pocket, but also in regions not directly involved in catalysis, in loops and/or mobile subparts (lids) (Wolf-Watz et al. 2004; Papaleo et al. 2008). It has been proposed that the high flexibility of cold-active enzymes facilitates the positioning of the substrate in the active site at low energy cost, resulting in high specific activities but also generally in heat lability and low substrate affinity (Lonhienne et al. 2000; Cavicchioli et al. 2002; Siddiqui and Cavicchioli 2006; Roca et al. 2007; Feller 2010; Struvay and Feller 2012).

Cold-active lipases have been mostly identified in psychrophilic organisms, yet some have also been characterized from mesophilic yeasts such as Pichia lynferdii (Kim et al. 2010; Park et al. 2013) and Candida albicans (Lan et al. 2011). Interestingly, the cold-adapted lipase CaLIP5 from C. albicans
(Lan et al. 2011) can be classified into the superfamily of the thermostable CaLA lipase from Pseudozyma (Candida) antarctica (Fig. 1), both enzymes exhibiting $34 \%$ of identity in their primary sequence. In spite of the original habitat of the strain, $P$. antarctica was shown to grow in $5-32{ }^{\circ} \mathrm{C}$ temperature range (Goto et al. 1969), and the enzyme CaLA has been shown to exhibit exceptionally high thermal stability, allowing applications at temperatures superior to $90{ }^{\circ} \mathrm{C}$ (Heldt-Hansen Hans et al. 1989; Domínguez de María et al. 2005). CaLA has be extensively studied (Sandstrom et al. 2009; Engström et al. 2010; Naik et al. 2010; Brenneis and Baeck 2012; Sandstrom et al. 2012), and homologous enzymes are considered to constitute an original group of lipases, with low structural homologies with other characterized lipases (Ericsson et al. 2008; Kourist et al. 2010; Widmann et al. 2010; Brundiek et al. 2012).

The present work aimed at studying the effect of a large range of temperatures $\left(5-80{ }^{\circ} \mathrm{C}\right)$ on the hydrolysis and alcoholysis activities in bi-phasic aqueous medium (lipid as organic phase, emulsified in buffer as aqueous phase) of four recombinant lipases of the CaLA superfamily, heterologously produced in Pichia pastoris: CpLIP2 from Candida parapsilosis CBS 604, CtroL4 from Candida tropicalis MYA-3404, AflaL0 from Aspergillus flavus NRRL3357 and CaLA (Neang et al. 2013). In similar experimental conditions, our group has already shown that CpLIP2 and CtroL4 exhibited an exceptional acyltransferase activity (Briand et al. 1995a; Neang et al. 2013) and thus appear as perfect candidates for the development of greener biocatalytic processes compare to those conducted in organic solvents. Indeed, compared to "classical" lipases, these two lipases/acyltransferases catalyse acyltransfer to various nucleophiles (e.g. alcoholysis reaction) preferentially to hydrolysis even in aqueous media with high thermodynamic activity of water $\left(a_{\mathrm{w}}>0.9\right)$, resulting in a kinetically controlled synthesis (Lecointe et al. 1996; Gianese et al. 2002, 2002; Neang et al. 2013) and offering great potential for example for the lipophilization of polar substrates (Villeneuve 2007; Husson et al. 2011). The catalysed reaction indeed results in a transesterification ratio superior to that obtained with the thermodynamic equilibrium of the esterification reaction. The interest of such kinetically controlled reactions has been described for acyltransfer catalysis in water abundant media, such as for the synthesis of peptides bonds using proteases or for amine-acylation catalysed by penicillin-acylases (Riechmann and Kasche 1984, 1985; Kasche 1986; Morihara 1987; Gololobov et al. 1993; Guranda et al. 2001; Chilov et al. 2003; Kumar and Bhalla 2005; Bahamondes et al. 2012).

The four lipases presented here exhibit 31 to $58 \%$ of identity in their primary sequences, and even if CaLA is currently the only one with a 3D structure elucidated by Xray diffraction (Ericsson et al. 2008), our goal was also to contribute through functional characterizations to a better 
Fig. 1 Distance tree of the proteins of the CaLA superfamily, with its four families as described in the Lipase Engineering Database: (1) C. antarctica lipase A like; (2) C. albicans lipase like; (3) Aspergillus lipase like; (4) Malassezia lipase like. Enzymes highlighted in light grey, dark grey and black are respectively cold-adapted, mesophilic and thermophilic; Asterisk (*) enzymes with acyltransferase ability demonstrated in aqueous media

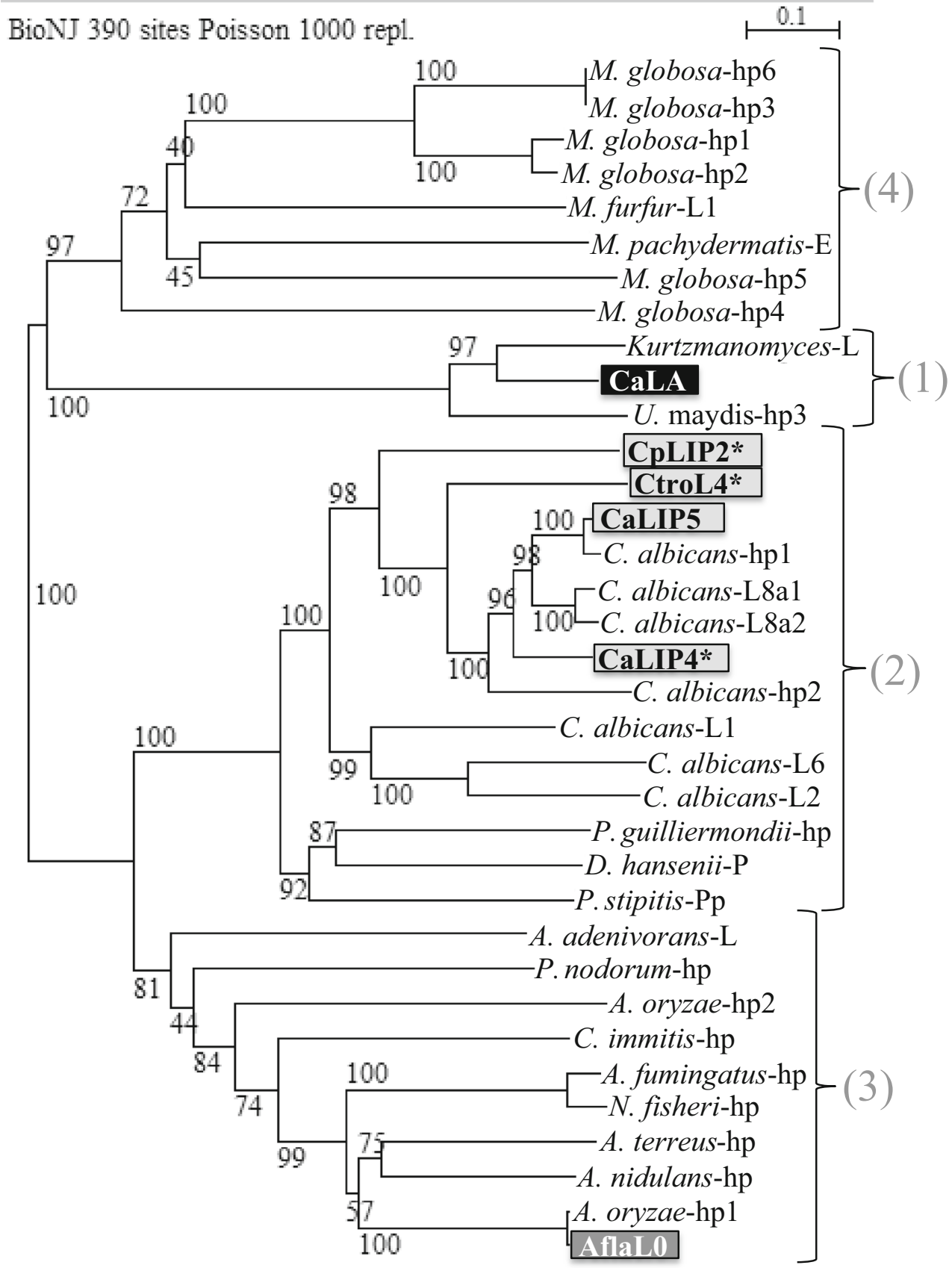

understanding of the various specificities and thermostability exhibited by such homologous proteins and to provide data to the homology models currently under study in our group.

\section{Materials and methods}

Sequence analysis

Proteins sequences of the CaLA superfamily were obtained from the Lipase Engineering Database (Fischer and Pleiss 2003). Sequence visualization, multisequence alignments and distance trees (BioNJ, Poisson, bootstrap 1000) were generated using Seaview (Galtier et al. 1996). Protein families are organized on the level of homologous families and superfamilies based on their sequence similarity. Protein sequence identity was obtained using the SIM alignment tool for protein sequences program (Huang and Miller 1991).

Recombinant enzymes

Recombinant CpLIP2, CtroL4, AflaL0 and CaLA were obtained from culture supernatant of transformed $P$. pastoris as previously described by Brunel et al. (2004) and Neang et al. 
(2013). Briefly, cultivations were performed using a synthetic medium containing only minerals, biotin, glycerol or methanol (carbon and energy source) and ammonia (nitrogen source). At the end of the culture, the enzyme extracts were first concentrated by ultrafiltration and then submitted to a diafiltration against pure water, so that no significant amount of minerals or low molecular mass compounds was present in the final extract (cut-off 30,000 Da).

\section{Enzymatic assays}

Hydrolysis and transesterification (or "acyltransfer" or "alcoholysis") activities were respectively determined by measuring the initial rates of fatty acid and of ester production $\left(\mu \mathrm{mol} \mathrm{min}^{-1}\right)$ in aqueous emulsions as described below. Specific activities were calculated in relation to protein concentration. The transesterification ratio is the percentage of alcoholysis rate vs the total activity rate (hydrolysis + alcoholysis) in the same conditions (in the presence of $2.2 \mathrm{M}$ methanol in this study). Results are expressed as the mean of three independent repeats \pm standard deviation.

Experiments were conducted as previously described (Vaysse et al. 2002; Neang et al. 2013) with the following modifications. Lipid substrates were prepared as emulsions consisting of $100 \mathrm{mM}$ lipid emulsified by sonication (Branson Sonifier 250, $20 \mathrm{~s}, 200 \mathrm{~W}, 145 \mu \mathrm{m}$ amplitude) in an aqueous solution of $20 \mathrm{~g} \mathrm{~L}^{-1}$ poly(vinyl alcohol). For reactions (total volume $1 \mathrm{~mL}$ in stoppered glass tubes), $100 \mu \mathrm{L}$ of the lipid substrate emulsion were added to $800 \mu \mathrm{L}$ of $50 \mathrm{mM}$ sodium phosphate buffer, $\mathrm{pH} 6.5$, eventually containing $2.2 \mathrm{M}$ methanol for transesterification assays. After $45 \mathrm{~s}$ of preheating of the reaction medium, reactions were started by the addition of $100 \mu \mathrm{L}$ of enzyme solution in the same buffer. The amount of enzyme was adapted for each biocatalyst so as to be in conditions where the rate of hydrolysis of ethyl oleate was detectable, proportional to protein concentration and constant during $15 \mathrm{~min}(0.002,0.002,0.13$ and $0.115 \mathrm{mg}$ proteins (eq. CpLIP2) in $1 \mathrm{~mL}$ of reaction medium for CpLIP2, CtroL4, $\mathrm{CaLA}$ and AflaL0, respectively). After $15 \mathrm{~min}$, reactions were stopped by the addition of $950 \mu \mathrm{L}$ of an ethanol/sulphuric acid $(100: 0.8, v / v)$ mixture. After the addition of $50 \mu \mathrm{L}$ of internal standards (ethanolic solution of pentadecanoic acid and its ethyl and methyl esters, $1 \mu \mathrm{mol}$ each), lipids were extracted with $1 \mathrm{~mL}$ of hexane. Esters and free fatty acids were then analysed by gas chromatography (GC) as follows: Hexane extracts $(200 \mu \mathrm{L})$ were reacted with $25 \mu \mathrm{L}$ pyridine and $25 \mu \mathrm{L}$ $N$-methyl- $N$-(trimethylsilyl)-trifluoroacetamide (MSTFA) as silylating agent. After heating at $50{ }^{\circ} \mathrm{C}$ for $20 \mathrm{~min}$, samples were ready for analysis. A Hewlett-Packard 5890 GC system equipped with a flame ionization detector, an automatic sampler (sample volume $0.5 \mu \mathrm{L}$ ) and a split/splitless injector was used for analysis. The capillary column was a DB-5ht $(15 \mathrm{~m} \times$ $0.25 \mathrm{~mm}, \mathrm{~J} \& W$ Scientific, Massy, France). The helium carrier flow was $2 \mathrm{~mL} \mathrm{~min}^{-1}$ and the split ratio was 1:18. Temperature conditions were, for reactions with individual substrates: injector $280{ }^{\circ} \mathrm{C}$, detector $290{ }^{\circ} \mathrm{C}$, oven 200 to $225^{\circ} \mathrm{C}$ at $10{ }^{\circ} \mathrm{C} \mathrm{min}^{-1}$.

Calibration curves were realized using emulsions of mixtures of FA and monoesters prepared according to the same protocol, without enzyme and alcohol.

\section{Protein analysis}

Protein concentrations in enzymatic extracts were determined by the Bradford method (Bradford 1976) using pure, lyophilized CpLIP2 as standard. Results are therefore given in milligrams equivalent of CpLIP2. As enzyme extracts were obtained from a synthetic cultivation medium then diafiltrated against pure water, no interference could be expected between the Bradford assay and peptides or salts.

\section{Results}

The catalytic activities of CpLIP2, CtroL4, AflaL0 and CaLA in a temperature range of 5 to $80^{\circ} \mathrm{C}$ were evaluated in parallel for both hydrolysis and alcoholysis of ethyl oleate (C18:1EE). Reactions were performed in buffered aqueous emulsions at $\mathrm{pH} 6.5$ with or without $2.2 \mathrm{M}$ methanol. The $\mathrm{pH}$ chosen was in the optimal activity range ( $>85 \%$ of the maximal activity) at $30{ }^{\circ} \mathrm{C}$ for the four enzymes (data not shown).

First, the four enzymes exhibited significant differences of specific activities and transesterification ratios. CpLIP2 and CtroL4 exhibited exceptionally high specific activities (respective maxima of $81-88$ and $86-100 \mu \mathrm{mol} \mathrm{min}^{-1}$ ) and transesterification ratios (respective average transesterification ratios of 97 and $87 \%$ ) compared to CaLA and AflaL0 (respectively $3-3.5 \mu \mathrm{mol} \mathrm{min}{ }^{-1}$ and $57 \%$ of transesterification and $1.3-1.5 \mu \mathrm{mol} \mathrm{min}{ }^{-1}$ and $46 \%$ of transesterification). These results confirm the exceptional level of specific activities and transesterification ratios obtained with CpLIP2 and CtroL4 in our previous study (Neang et al. 2013). With CpLIP2 and CtroL4, the transesterification ratios were only slightly affected by temperature in the presence of $2.2 \mathrm{M}$ methanol (less than $3 \%$ variation), while with CaLA, it increased with the increase of temperature (from $46 \%$ at $5{ }^{\circ} \mathrm{C}$ to $67 \%$ at $80{ }^{\circ} \mathrm{C}$ ), and with AflaL0, more variations were observed (38 to $52 \%$ ). Three behaviours were observed among the four enzymes in the conditions of temperature variation tested (Fig. 2):

(1) For CpLIP2 and CtroL4, the highest specific activity was observed between 35 and $45^{\circ} \mathrm{C}$ in the absence of methanol and around $30^{\circ} \mathrm{C}$ in the presence of $2.2 \mathrm{M}$ methanol. No activity was detected at $60^{\circ} \mathrm{C}$ and higher. Below $30{ }^{\circ} \mathrm{C}$, the reaction rates decreased slowly with 
Fig. 2 Influence of temperature on catalytic activity of enzymes CpLIP2 (a), CtroL4 (b), AflaL0 (c) and CaLA (d) in condition without alcohol (black-filled circles $(\bullet)$ hydrolysis activity) and in transesterification condition with $\mathrm{MeOH}$ (black-filled triangle (A)alcoholysis activity; white triangle $(\Delta)$ total activity (=alcoholysis + competitive hydrolysis)). Reactions were performed at desired temperature, $\mathrm{pH} 6.5$ in the presence of $10 \mathrm{mM}$ of ethyl oleate in PVA emulsion, and eventually $2.2 \mathrm{M}$ methanol
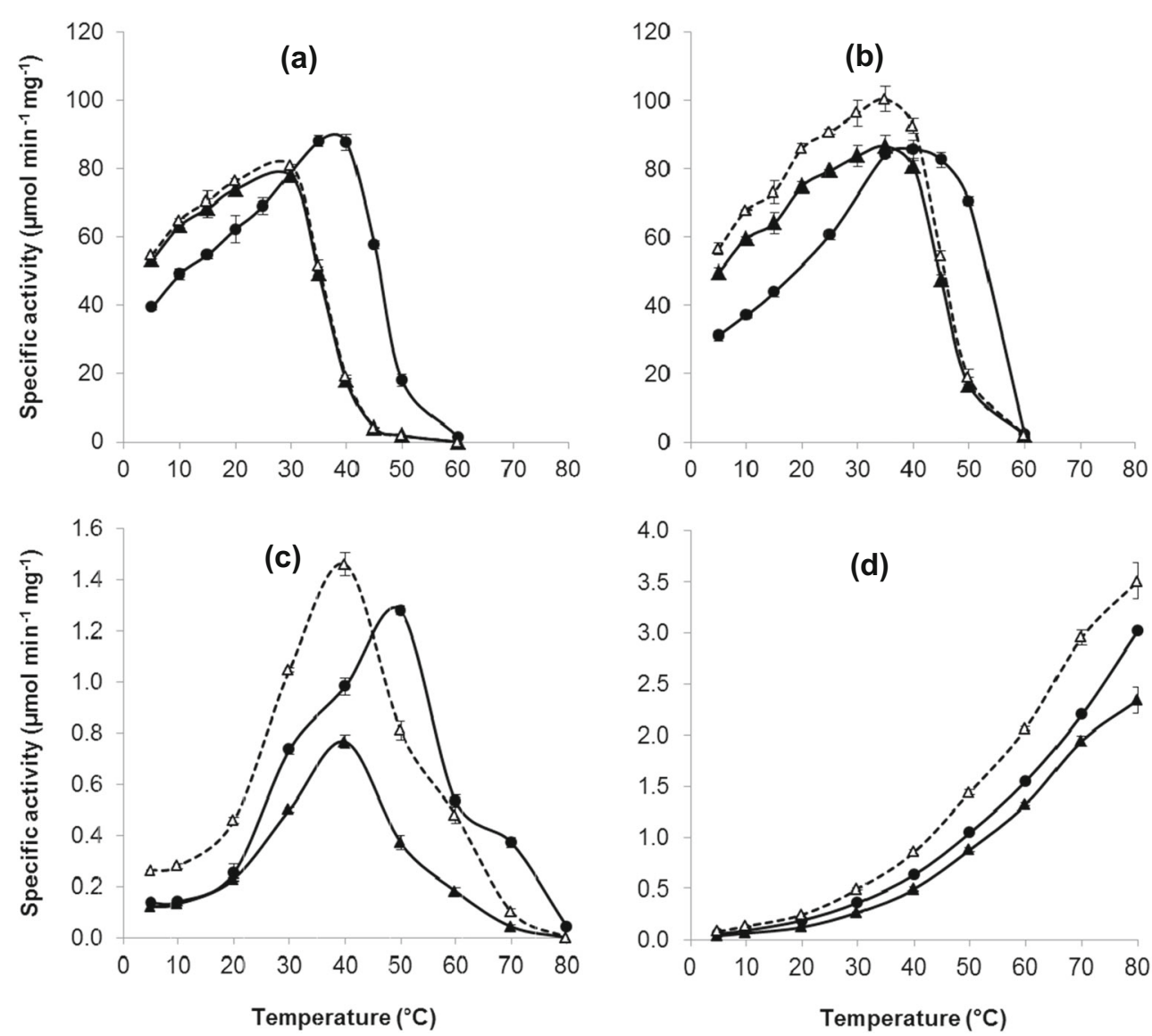

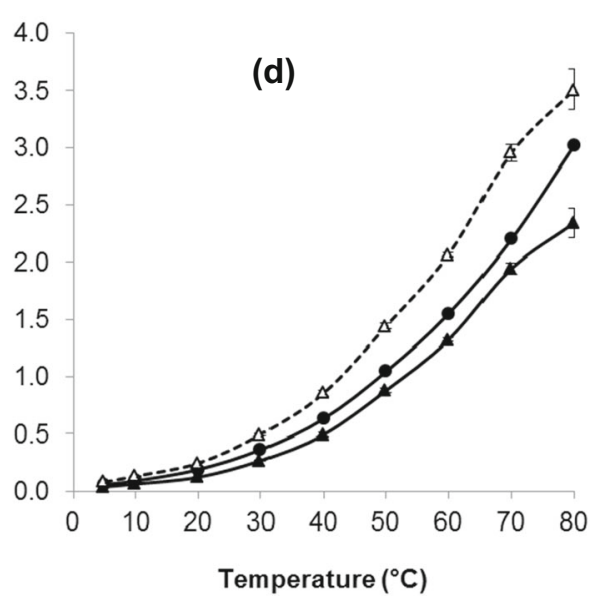

decreasing temperatures, with both enzymes preserving a high catalytic activity at $5{ }^{\circ} \mathrm{C}(>30 \%$ of the maximum, up to $65 \%$ for CpLIP2 in alcoholysis conditions).

(2) For AflaL0, the highest rates of transesterification and hydrolysis were observed between 40 and $50{ }^{\circ} \mathrm{C}$ in the conditions tested. Above $50{ }^{\circ} \mathrm{C}$, the reaction rates decreased regularly with temperature up to $80^{\circ} \mathrm{C}$, where no activity could be detected. At $5^{\circ} \mathrm{C}$, the specific activity of AflaL0 was only $20 \%$ of its maximal value (i.e. at $50{ }^{\circ} \mathrm{C}$ for hydrolytic conditions and $40{ }^{\circ} \mathrm{C}$ in the presence of methanol).

(3) With CaLA, the specific activity continuously increased up to the maximum temperature tested $\left(80{ }^{\circ} \mathrm{C}\right)$, which confirms the exceptional thermophilic characteristics of CaLA previously described (Bosley et al. 1997; Nielsen et al. 1999; Lund et al. 2000), even in biphasic aqueous media. In comparison, CpLIP2, CtroL4 and AflaL0 were thus less thermostable, even if, at $60{ }^{\circ} \mathrm{C}$, AflaL0 still exhibited 24 and $42 \%$ of its respective acyltransfer and hydrolysis maximal activities.

The presence of $2.2 \mathrm{M}$ methanol seemed to have a negative impact on the stability of the four enzymes (although only a tendency can be observed for CaLA at $65-80^{\circ} \mathrm{C}$ ), leading to a $5-10{ }^{\circ} \mathrm{C}$ lower value of the temperature at which the highest reaction rates were recorded (Fig. 2). Indeed, methanol allowed high levels of catalytic activity at moderate temperatures, but appeared, at high temperature, to have a destabilizing effect and to be favourable to enzyme denaturation.

The relatively low thermostability of CpLIP2 and CtroL4 was counterbalanced by interesting cold-active properties. Indeed, at $5{ }^{\circ} \mathrm{C}, \mathrm{CpLIP} 2$ and $\mathrm{CtroL} 4$ preserved respectively 68 and $57 \%$ of their maximum acyltransfer activity (78 $\mu \mathrm{mol} \mathrm{min} \mathrm{mg}^{-1}$ at $30{ }^{\circ} \mathrm{C}$ for $\mathrm{CpLIP} 2$ and $87 \mu \mathrm{mol} \mathrm{min}{ }^{-1} \mathrm{mg}^{-1}$ at $35^{\circ} \mathrm{C}$ for CtroL4) and 45 and $36 \%$ of their optimum hydrolysis activity $\left(88 \mu \mathrm{mol} \mathrm{min}{ }^{-1} \mathrm{mg}^{-1}\right.$ at $40{ }^{\circ} \mathrm{C}$ for $\mathrm{CpLIP} 2$ and $86 \mu \mathrm{mol} \mathrm{min}{ }^{-1} \mathrm{Mg}^{-1}$ at $40{ }^{\circ} \mathrm{C}$ for CtroL4). At $5{ }^{\circ} \mathrm{C}$, AflaL0 and CaLA only preserved respectively $10-16$ and $2-4 \%$ of their activities compared to the highest activities (obtained at $40-50{ }^{\circ} \mathrm{C}$ for AflaL0 and at $80^{\circ} \mathrm{C}$ for CaLA). Comparison of the specific activities of the four enzymes at 5 and $30{ }^{\circ} \mathrm{C}$ confirmed that CpLIP2 was the most cold-active lipase (with residual activities of 55 and $68 \%$ at $5{ }^{\circ} \mathrm{C}$ compared to those obtained respectively in hydrolysis and alcoholysis condition at $30^{\circ} \mathrm{C}$ ), followed by CtroL4 (48$59 \%$ of residual activity) while at $5{ }^{\circ} \mathrm{C}$ AflaL 0 and CaLA only conserved respectively $19-25$ and $16 \%$ of their total activity at $30^{\circ} \mathrm{C}$.

Activation energy $E_{\mathrm{A}}$ of the reactions, calculated on the exponential parts of the curves (Fig. 2) using the Arrhenius 
model, showed that CpLIP2 and CtroL4 exhibited remarkable low $\mathrm{E}_{\mathrm{A}}$, especially for the alcoholysis reaction (Table 1). Indeed, compared to the classical lipases CaLA and AflaL0, for which the average $E_{\mathrm{A}}$ was $43 \mathrm{~kJ} \mathrm{~mol}^{-1}, \mathrm{CpLIP} 2$ and CtroL4 exhibited an average $E_{\mathrm{A}}$ of 17 and $18 \mathrm{~kJ} \mathrm{Mol}^{-1}$, respectively. For both enzymes, the activation energy of the transesterification reaction $\left(\sim 15 \mathrm{~kJ} \mathrm{~mol}^{-1}\right)$ was lower than that of the hydrolysis reaction $\left(17-23 \mathrm{~kJ} \mathrm{~mol}^{-1}\right)$. Combined to their high specific activity, these results confirmed that CpLIP2 and CtroL4 are highly efficient cold-active lipases/ acyltransferases.

\section{Discussion}

Like previously described, in the presence of methanol, CpLIP2 and CtroL4 displayed an exceptional level of acyltransferase activity compared to CaLA and AflaL0, with average transesterification ratios (alcoholysis vs alcoholysis +hydrolysis in the same conditions) of 97, 87, 57 and $46 \%$, respectively, in the presence of $2.2 \mathrm{M}$ methanol. These transesterification ratios were only slightly influenced by the reaction temperature, but acyltransfer was favoured by decreasing temperature as the maximum transesterification rates (with alcohol) were obtained at lower temperature than the maximum hydrolysis rates (without alcohol), in accordance with temperature influence proposed by Kasche (1986). In our experiments, the water phase, containing the enzyme and eventually alcohol (methanol), exhibited high water activity $\left(a_{\mathrm{w}}>0.9\right)$ and was simply emulsified with the lipid substrate (ethyl oleate in poly(vinyl alcohol) as emulsifier, without organic solvent). When methanol was present, three reactions were possible (in initial conditions): (1) production of oleic acid by hydrolysis of ethyl oleate, (2) production of methyl oleate by alcoholysis (or "acyltransfer" or "transesterification") of ethyl oleate and (3) production of methyl oleate by esterification of the firstly produced oleic acid. According to our former studies, it is was proposed that

Table 1 Activation energy $\mathrm{E}_{\mathrm{A}}$ for each catalytic reaction (hydrolysis in condition without methanol, transesterification and competitive hydrolysis in the presence of $2.2 \mathrm{M}$ methanol) at a temperature range of $5-35^{\circ} \mathrm{C}$ in the presence of each of the four enzymes tested: CpLIP2, CtroL4, CaLA and AflaL0

Activation energy $\left(\mathrm{kJ} \mathrm{mol}^{-1}\right)$

\begin{tabular}{lllll}
\hline Enzyme & Hydrolysis & Alcoholysis & $\begin{array}{l}\text { Competitive } \\
\text { hydrolysis }\end{array}$ & $\begin{array}{l}\text { Mean } \pm \text { standard } \\
\text { deviation }\end{array}$ \\
\hline CpLIP2 & 17.5 & 14.5 & 18.1 & $16.7 \pm 1.8$ \\
CtroL4 & 22.6 & 14.7 & 16.6 & $18.0 \pm 1.6$ \\
CaLA & 43.0 & 47.1 & 40.2 & $43.5 \pm 3.5$ \\
AflaL0 & 44.4 & 44.6 & 40.9 & $43.3 \pm 2.1$ \\
\hline
\end{tabular}

the competition between water and the other nucleophile as acyl acceptor group was modulated by both the chemical reactivity of the competitive reactants, through their relative thermodynamic activity and by intrinsic properties of the biocatalysts that will preferentially catalyse either hydrolysis or alcoholysis reactions in the deacylation step of the catalytic mechanism (Briand et al. 1995a, b; Lecointe et al. 1996; Vaysse et al. 2002; Neang et al. 2013), as described for other lipases (Bousquet-Dubouch et al. 2001; Ma et al. 2002; Graber et al. 2003a; Graber b; Adlercreutz 2013). Here, the slight differential effect of temperature on alcoholysis and competitive hydrolysis observed could not be explained by an effect of temperature on the thermodynamic activities of alcohol and water. UNIFAC calculations (Magnussen et al. 1981) suggest indeed a $\sim 2 \%$ increase of the thermodynamic activity of methanol with almost constant water activity when temperature raises from 5 and $30{ }^{\circ} \mathrm{C}$ in the conditions of our experiments. Therefore, it was mainly the intrinsic properties of the biocatalysts that either determined a kinetically controlled synthesis with a superior transesterification ratio obtained with the lipases/acyltransferases CpLIP2 and CtroL4, or an equilibrium control synthesis with an inferior transesterification ratio obtained with the classical lipases CaLA and AflaL0 (in theory $\sim 70 \%$ alcoholysis at the thermodynamic equilibrium at $2.2 \mathrm{M}$ methanol).

In addition, we showed that CpLIP2 and CtroL4 displayed exceptionally low activation energy, particularly for the alcoholysis reaction. Low values of $E_{\mathrm{A}}$ are typical of coldactive lipases from different organisms such as Psychrobacter sp. (Parra et al. 2008), Antarctic Bacillus pumilus strains (Litantra et al. 2013) and Photocacterium strain (Kim et al. 2012), which displayed $E_{\mathrm{A}}$ of 23,18 and $11.3 \mathrm{~kJ} \mathrm{~mol}^{-1}$, in the conditions of the respective studies. In comparison, CaLIP5, the previously identified cold-active lipase belonging to the CaLA superfamily, showed higher activation energy for hydrolysis $\left(36 \mathrm{~kJ} \mathrm{~mol}^{-1}\right)$, in a temperature range of $5-25{ }^{\circ} \mathrm{C}$ above which its enzymatic rate decreased (Lan et al. 2011). The other homologous lipase CaLIP4 (60\% homology with CpLIP2), studied in a temperature range of $20-50{ }^{\circ} \mathrm{C}$, was shown to exhibit comparable $E_{\mathrm{A}}$ to CpLIP2 and CtroL4 for the transesterification reaction $\left(18 \mathrm{~kJ} \mathrm{~mol}^{-1}\right)$ but significantly higher $E_{\mathrm{A}}$ for hydrolysis alone $\left(46 \mathrm{~kJ} \mathrm{~mol}^{-1}\right.$ ) (Roustan et al. 2005).

Besides, CpLIP2 and CtroL4, very active at $5{ }^{\circ} \mathrm{C}$, were nearly totally inactivated at $60{ }^{\circ} \mathrm{C}$ while AflaL0 and CaLA displayed very limited activities at low temperature. These results suggest that cold-active properties and thermostability of this group of enzymes are mutually exclusive, which is not always the case (Fedøy et al. 2007; Florczak et al. 2013). The thermolability of cold-adapted lipases is well known in literature (Feller et al. 1991; Gerday et al. 2000), and most coldevolved lipases typically lose their hydrolysis activity at temperature higher than $25-35^{\circ} \mathrm{C}$ (Kim et al. 2010; Lan et al. 
2011; Tanaka et al. 2012; Litantra et al. 2013), including CaLIP5 for which the optimum hydrolysis activity was observed at $25^{\circ} \mathrm{C}$ (Lan et al. 2011). In comparison, the apparent higher stability of CpLIP2 and CtroL4 (optimum at $30-40{ }^{\circ} \mathrm{C}$ in the conditions tested here) could be particularly efficient for specific applications at ambient temperature (no need for cooling or heating). Besides, improvement of these biocatalysts stability could be achieved by enzymes immobilization (Iyer and Ananthanarayan 2008; Cowan and Fernandez-Lafuente 2011; Garcia-Galan et al. 2011; Hwang and Gu 2013; Rodrigues et al. 2013) as it has already been shown for CpLIP2 (Osorio et al. 2009a).

The functional characterization of different members of the same protein superfamily is an interesting approach for a better understanding of the specificities of this group and its subgroups. Here, we demonstrate that, within the CaLA superfamily, cold-active enzymes are found within the C. albicans lipase-like family (Widmann et al. 2010) (Fig. 1), which exhibit more than $58 \%$ mutual identity in their primary sequences. In addition, acyltransfer ability and cold activity could be related to common structural determinants shared by CpLIP2, CtroL4 and CaLIP4, the best currently described acyltransferases of the superfamily. This might be related to the higher flexibility of these proteins which might favour the positioning of larger nucleophiles than water in the active site (the lower the $E_{\mathrm{A}}$, the higher the transesterification rate). Furthermore, the particularly high specific activities exhibited by CpLIP 2 and CtroL 4 also support the proposition that the high flexibility and/or local instability of cold-active enzymes could enable an increased complementarity between the active site and the substrate transition state with a low activation barrier, resulting in high specific activities at low temperatures (Cavicchioli et al. 2002; Roca et al. 2007). Classical sequence-based features acting on flexibility such as the proportion of arginine vs lysine residues, the number of proline, hydrophobic or charged residues have not been evidenced compared to their thermophilic biocatalysts. However, because the four enzymes described here are homologous, further elucidation and comparisons of their 3D structures should lead path for the design of valuable thermostable lipase/acyltransferases.

In conclusion, after investigating the ability of CpLIP2, CtroL4, AflaL0 and CaLA to catalyse both hydrolysis and alcoholysis reactions in aqueous medium $\left(a_{\mathrm{w}}>0.9\right)$ at extreme conditions of temperature, CpLIP2 and CtroL4 were shown to be cold-active lipases/acyltransferases, which displayed at $5{ }^{\circ} \mathrm{C}, 45-68$ and $35-57 \%$ of their optimum activities obtained at $30-40{ }^{\circ} \mathrm{C}$. To the contrary, AflaL0 and CaLA were only slightly active at $5{ }^{\circ} \mathrm{C}$ and displayed a maximum specific activity at higher temperatures $\left(40-50{ }^{\circ} \mathrm{C}\right.$ for AflaL0 and higher than $80^{\circ} \mathrm{C}$ for CaLA). The activity of CaLA increased steadily with the increase of temperature from 5 to $80{ }^{\circ} \mathrm{C}$, illustrating its already known exceptional thermostability. It is interesting to note that contrary to most previously described cold-adapted enzymes, which are from psychrophilic microorganisms; CpLIP2 and CtroL4 are produced by mesophilic C. parapsilosis and C. tropicalis strains (unexpectedly, $C$. tropicalis produces a cold-active enzyme while $P$. antarctica produces a thermostable one). The activation energy of the reactions catalysed by the two lipase/acyltransferases CpLIP2 and CtroL4 was on average $60 \%$ lower than that of the CaLA and AflaL0 lipases $(70 \%$ lower when considering the alcoholysis reaction) and was associated with a high specific activity, demonstrating the high catalytic efficiency of these enzymes.

In addition to their peculiar ability to catalyse acyltransfer reactions in aqueous medium and other properties as previously reported (Briand et al. 1994; 1995a, b, c; Vaysse 1997; Neugnot et al. 2002; Osorio et al. 2009a; b; Tecelão et al. 2010; Husson et al. 2011; Neang et al. 2013), the cold-active properties of lipases such as the lipase/acyltransferase CpLIP2 have thus a potential interest for the reduction of the energy cost of the processes by avoiding heating and/or for industrial applications requiring cold to mild process conditions, such as for the synthesis or lipophilization of thermosensitive or highly reactive lipids derivatives. The lipases/acyltransferases studied here could be used in their free or immobilized form, in aqueous media containing small amounts of a nucleophile acceptor (e.g. alcohol) and directly emulsified with lipid substrates, without the use of organic solvent or control of $a_{\mathrm{w}}$. The other advantage of such a process is that the recovery of the lipids products can be achieved by simple lipid/water separation and that the enzyme can be easily recycled, even in its free form by direct reusing of the water phase. We show here that the subgroup of the C. albicans lipase-like family in the CaLA superfamily of the Lipase Engineering Database (Widmann et al. 2010) comprises cold-adapted enzymes with exceptional acyltransferase properties in biphasic aqueous media. Common structural features of this group of enzymes might thus be favourable not only to the cold-activity but also to the acyltransfer ability. Further studies on the structure and properties of this group of exceptional enzymes are currently conducted in order to better understand their structurefunction relationships.

Acknowledgments Authors thank the French Embassy in Cambodia and Montpellier SupAgro for their financial support.

\section{References}

Adlercreutz P (2013) Immobilisation and application of lipases in organic media. Chem Soc Rev 42:6406-6436

Arpigny JL, Lamotte J, Gerday C (1997) Molecular adaptation to cold of an Antarctic bacterial lipase. J Mol Catal B: Enzym 3:29-35

Bahamondes C, Wilson L, Aguirre C, Illanes A (2012) Comparative study of the enzymatic synthesis of cephalexin at high substrate 
concentration in aqueous and organic media using statistical model. Biotechnol Bioprocess Eng 17:711-721

Bosley JA, Casey J, Macrae AR and MyCock G (1997) Process for the esterification of carboxylic acids with tertiary alcohols using a lipase from Candida antarctica. United States Patent. 5658769

Bousquet-Dubouch MP, Graber M, Sousa N, Lamare S, Legoy MD (2001) Alcoholysis catalyzed by Candida antarctica lipase B in a gas/solid system obeys a Ping Pong Bi Bi mechanism with competitive inhibition by the alcohol substrate and water. Biochim Biophys Acta 1550:90-99

Bradford MM (1976) A rapid and sensitive method for the quantitation of microgram quantities of protein utilizing the principle of protein-dye binding. Anal Biochem 72:248-254

Brenneis R, Baeck B (2012) Esterification of fatty acids using Candida antarctica lipase A in water-abundant systems. Biotechnol Lett 34: 1459-1463

Briand D, Dubreucq E, Galzy P (1994) Enzymatic Fatty esters synthesis in aqueous-medium with lipase from Candida parapsilosis (Ashford) Langeron and Talice. Biotechnol Lett 16:813-818

Briand D, Dubreucq E, Galzy P (1995a) Functioning and regioselectivity of the lipase of Candida parapsilosis (Ashford) Langeron and Talice in aqueous medium. New interpretation of regioselectivity taking acyl migration into account. Eur J Biochem 228:169-175

Briand D, Dubreucq E, Galzy P (1995b) Factors affecting the acyltransfer activity of the lipase from Candida parapsilosis in aqueous media. $\mathrm{J}$ Am Oil Chem Soc 72:1367-1373

Briand D, Dubreucq E, Grimaud J, Galzy P (1995c) Substrate-Specificity of the lipase from Candida parapsilosis. Lipids 30:747-754

Brundiek H, Saß S, Evitt A, Kourist R, Bornscheuer UT (2012) The short form of the recombinant CAL-A-type lipase UM03410 from the smut fungus Ustilago maydis exhibits an inherent trans-fatty acid selectivity. Appl Microbiol Biotechnol 94:141-150

Brunel L, Neugnot V, Landucci L, Boze WN, Moulin G, Bigey F, Dubreucq E (2004) High-level expression of Candida parapsilosis lipase/acyltransferase in Pichia pastoris. J Biotechnol 111:41-50

Casanueva A, Tuffin M, Cary C, Cowan DA (2010) Molecular adaptations to psychrophily: the impact of 'omic' technologies. Trends Microbiol 18:374-381

Cavicchioli R, Siddiqui KS, Andrews D, Sowers KR (2002) Lowtemperature extremophiles and their applications. Curr Opin Biotechnol 13:253-261

Chilov GG, Moody HM, Boesten WHJ, Švedas VK (2003) Resolution of (RS)-phenylglycinonitrile by penicillin acylase-catalyzed acylation in aqueous medium. Tetrahedron Asymmetry 14:2613-2617

Christopher LP, Hemanathan K, Zambare VP (2014) Enzymatic biodiesel: challenges and opportunities. Appl Energy 119:497-520

Cowan DA, Fernandez-Lafuente R (2011) Enhancing the functional properties of thermophilic enzymes by chemical modification and immobilization. Enzym Microb Technol 49:326-346

Domínguez de María P, Carboni-Oerlemans C, Tuin B, Bargeman G, van der Meer A, van Gemert R (2005) Biotechnological applications of Candida antarctica lipase A: state-of-the-art. J Mol Catal B: Enzym 37:36-46

Engström K, Nyhlén J, Sandström AG, Bäckvall J-E (2010) Directed evolution of an enantioselective lipase with broad substrate scope for hydrolysis of $\alpha$-substituted esters. J Am Chem Soc 132:70387042

Ericsson DJ, Kasrayan A, Johansson P, Bergfors T, Sandström AG, Bäckvall J-E, Mowbray SL (2008) X-ray structure of Candida antarctica lipase A shows a novel lid structure and a likely mode of interfacial activation. J Mol Biol 376:109-119

Fedøy A-E, Yang N, Martinez A, Leiros H-KS, Steen IH (2007) Structural and functional properties of isocitrate dehydrogenase from the psychrophilic bacterium Desulfotalea psychrophila reveal a cold-active enzyme with an unusual high thermal stability. J Mol Biol 372:130-149
Feller G (2010) Protein stability and enzyme activity at extreme biological temperatures. J Phys Condens Matter 22:0953-8984

Feller G, Thiry M, Gerday C (1991) Nucleotide sequence of the lipase gene lip3 from the antarctic psychotroph Moraxella TA144. Biochim Biophys Acta 1088:323-324

Fischer M, Pleiss J (2003) The Lipase Engineering Database: a navigation and analysis tool for protein families. Nucleic Acids Res 31:319 321

Florczak T, Daroch M, Wilkinson MC, Bialkowska A, Bates AD, Turkiewicz M, Iwanejko LA (2013) Purification, characterisation and expression in Saccharomyces cerevisiae of LipG7 an enantioselective, cold-adapted lipase from the Antarctic filamentous fungus Geomyces $s p$. P7 with unusual thermostability characteristics. Enzym Microb Technol 53:18-24

Galtier N, Gouy M, Gautier C (1996) SEAVIEW and PHYLO_WIN: two graphic tools for sequence alignment and molecular phylogeny. Comput Appl Biosci 12:543-548

Garcia-Galan C, Berenguer-Murcia Á, Fernandez-Lafuente R, Rodrigues RC (2011) Potential of different enzyme immobilization strategies to improve enzyme performance. Adv Synth Catal 353:2885-2904

Gerday C, Aittaleb M, Bentahir M, Chessa JP, Claverie P, Collins T, D'Amico S, Dumont J, Garsoux G, Georlette D, Hoyoux A, Lonhienne T, Meuwis MA, Feller G (2000) Cold-adapted enzymes: from fundamentals to biotechnology. Trends Biotechnol 18:103107

Gianese G, Bossa F, Pascarella S (2002) Comparative structural analysis of psychrophilic and meso- and thermophilic enzymes. Proteins: Struct Funct Bioinform 47:236-249

Gololobov MY, Stepanov VM, Voyushina TL, Adlercreutz P (1993) The second nucleophile molecule binds to the acyl-enzyme-nucleophile complex in alpha-chymotrypsin catalysis. Kinetic evidence for the interaction. Eur J Biochem 217:955-963

Goto S, Sugiyama J, Iizuka H (1969) A taxonomic study of Antarctic yeasts. Mycologia 61:748-774

Graber M, Bousquet-Dubouch MP, Lamare S, Legoy MD (2003a) Alcoholysis catalyzed by Candida antarctica lipase B in a gas/ solid system: effects of water on kinetic parameters. Biochim Biophys Acta 1648:24-32

Graber M, Bousquet-Dubouch MP, Sousa N, Lamare S, Legoy MD (2003b) Water plays a different role on activation thermodynamic parameters of alcoholysis reaction catalyzed by lipase in gaseous and organic media. Biochim Biophys Acta 1645:56-62

Guranda DT, van Langen LM, van Rantwijk F, Sheldon RA, Švedas VK (2001) Highly efficient and enantioselective enzymatic acylation of amines in aqueous medium. Tetrahedron Asymmetry 12:1645-1650

Hasan F, Shah AA, Hameed A (2006) Industrial applications of microbial lipases. Enzym Microb Technol 39:235-251

Heldt-Hansen Hans P, Ishii M, Patkar Shamkant A, Hansen Tomas T, Eigtved P (1989) A new immobilized positional nonspecific lipase for fat modification and ester synthesis. Biocatalysis Agric Biotechnol Am Chem Soc 389:158-172

Hills G (2003) Industrial use of lipases to produce fatty acid esters. Eur J Lipid Sci Technol 105:601-607

Huang X, Miller W (1991) A time-efficient, linear-space local similarity algorithm. Adv Appl Math 12:337-357

Husson E, Humeau C, Harscoat C, Framboisier X, Paris C, Dubreucq E, Marc I, Chevalot I (2011) Enzymatic acylation of the polar dipeptide, carnosine: reaction performances in organic and aqueous media. Process Biochem 46:945-952

Hwang ET, Gu MB (2013) Enzyme stabilization by nano/microsized hybrid materials. Eng Life Sci 13:49-61

Iyer PV, Ananthanarayan L (2008) Enzyme stability and stabilizationaqueous and non-aqueous environment. Process Biochem 43:1019 1032

Jaeger KE, Eggert T (2002) Lipases for biotechnology. Curr Opin Biotechnol 13:390-397 
Jeon JH, Kim JT, Kim YJ, Kim HK, Lee HS, Kang SG, Kim SJ, Lee JH (2009) Cloning and characterization of a new cold-active lipase from a deep-sea sediment metagenome. Appl Microbiol Biotechnol 81:865-874

Joseph B, Ramteke PW, Thomas G (2008) Cold active microbial lipases: some hot issues and recent developments. Biotechnol Adv 26:457470

Kasche V (1986) Mechanism and yields in enzyme catalysed equilibrium and kinetically controlled synthesis of $\beta$-lactam antibiotics, peptides and other condensation products. Enzym Microb Technol 8:4-16

Kim HR, Kim IH, Hou CT, Kwon KI, Shin BS (2010) Production of a novel cold-active lipase from Pichia lynferdii Y-7723. J Agric Food Chem 58:1322-1326

Kim YO, Khosasih V, Nam BH, Lee SJ, Suwanto A, Kim HK (2012) Gene cloning and catalytic characterization of cold-adapted lipase of Photobacterium sp. MA1-3 isolated from blood clam. J Biosci Bioeng 114:589-595

Kourist R, Jochens H, Bartsch S, Kuipers R, Padhi SK, Gall M, Bottcher D, Joosten HJ, Bornscheuer UT (2010) The alpha/beta-hydrolase fold 3DM database (ABHDB) as a tool for protein engineering. ChemBioChem 11:1635-1643

Kumar D, Bhalla T (2005) Microbial proteases in peptide synthesis: approaches and applications. Appl Microbiol Biotechnol 68:726736

Lan DM, Yang N, Wang WK, Shen YF, Yang B, Wang YH (2011) A novel cold-active lipase from Candida albicans: Cloning, expression and characterization of the recombinant enzyme. Int J Mol Sci 12: 3950-3965

Lecointe C, Dubreucq E, Galzy P (1996) Ester synthesis in aqueous media in the presence of various lipases. Biotechnol Lett 18:869 874

Litantra R, Lobionda S, Yim JH, Kim HK (2013) Expression and biochemical characterization of cold-adapted lipases from Antarctic Bacillus pumilus strains. J Microbiol Biotechnol 23:1221-1228

Lonhienne T, Gerday C, Feller G (2000) Psychrophilic enzymes: revisiting the thermodynamic parameters of activation may explain local flexibility. Biochim Biophys Acta 1543:1-10

Lund H, Nilsson TE and Pickard T (2000) Treatment of fabrics. Patent US. 6077316

Ma L, Persson M, Adlercreutz P (2002) Water activity dependence of lipase catalysis in organic media explains successful transesterification reactions. Enzym Microb Technol 31:1024-1029

Magnussen T, Rasmussen P, Fredenslund A (1981) UNIFAC parameter table for prediction of liquid-liquid equilibria. Ind Eng Chem Process Des Dev 20:331-339

Morihara K (1987) Using proteases in peptide synthesis. Trends Biotechnol 5:164-170

Naik S, Basu A, Saikia R, Madan B, Paul P, Chaterjee R, Brask J, Svendsen A (2010) Lipases for use in industrial biocatalysis: Specificity of selected structural groups of lipases. J Mol Catal B: Enzym 65:18-23

Neang PM, Subileau M, Perrier V, Dubreucq E (2013) Peculiar features of four enzymes of the CaLA superfamily in aqueous media: differences in substrate specificities and abilities to catalyze alcoholysis. J Mol Catal B: Enzym 94:36-46

Neugnot V, Moulin G, Dubreucq E, Bigey F (2002) The lipase/ acyltransferase from Candida parapsilosis: molecular cloning and characterization of purified recombinant enzymes. Eur J Biochem 269:1734-1745

Nielsen TB, Ishii M and Kirk O (1999) Lipases A and B from the yeast Candida antarctica. Biotechnological applications of cold-adapted organisms. Margesin R and Schinner F. Springer, Berlin: 49-61

Osorio NM, Dubreucq E, da Fonseca MMR, Ferreira-Dias S (2009a) Operational stability of immobilised lipase/acyltransferase during interesterification of fat blends. Eur J Lipid Sci Technol 111:358367
Osorio NM, Dubreucq E, da Fonseca MMR, Ferreira-Dias S (2009b) Lipase/acyltransferase-catalysed interesterification of fat blends containing n-3 polyunsaturated fatty acids. Eur J Lipid Sci Technol 111:120-134

Papaleo E, Pasi M, Riccardi L, Sambi I, Fantucci P, Gioia LD (2008) Protein flexibility in psychrophilic and mesophilic trypsins. Evidence of evolutionary conservation of protein dynamics in trypsin-like serine-proteases. FEBS Lett 582:1008-1018

Park S-Y, Kim J-Y, Bae J-H, Hou CT, Kim H-R (2013) Optimization of culture conditions for production of a novel cold-active lipase from Pichia lynferdii NRRL Y-7723. J Agric Food Chem 61:882-886

Parra LP, Reyes F, Acevedo JP, Salazar O, Andrews BA, Asenjo JA (2008) Cloning and fusion expression of a cold-active lipase from marine Antarctic origin. Enzym Microb Technol 42:371-377

Riechmann L, Kasche V (1984) Kinetic studies on the mechanism and the specificity of peptide semisynthesis catalyzed by the serine proteases $\alpha$-chymotrypsin and $\beta$-trypsin. Biochem Biophys Res Commun 120:686-691

Riechmann L, Kasche V (1985) Peptide synthesis catalyzed by the serine proteinases chymotrypsin and trypsin. Biochim Biophys Acta 830: 164-172

Roca M, Liu H, Messer B, Warshel A (2007) On the relationship between thermal stability and catalytic power of enzymes. Biochemistry 46 : 15076-15088

Rodrigues RC, Ortiz C, Berenguer-Murcia A, Torres R, FernandezLafuente R (2013) Modifying enzyme activity and selectivity by immobilization. Chem Soc Rev 42:6290-6307

Roustan JL, Chu AR, Moulin G, Bigey F (2005) A novel lipase/ acyltransferase from the yeast Candida albicans: expression and characterisation of the recombinant enzyme. Appl Microbiol Biotechnol 68:203-212

Sandstrom AG, Engstrom K, Nyhlen J, Kasrayan A, Backvall JE (2009) Directed evolution of Candida antarctica lipase A using an episomaly replicating yeast plasmid. Protein Eng Des Sel 22:413420

Sandstrom AG, Wikmark Y, Engstrom K, Nyhlen J, Backvall JE (2012) Combinatorial reshaping of the Candida antarctica lipase A substrate pocket for enantioselectivity using an extremely condensed library. Proc Natl Acad Sci U S A 109:78-83

Siddiqui KS, Cavicchioli R (2006) Cold-adapted enzymes. Annu Rev Biochem 75:403-433

Smalås AO, Leiros H-KS, Os V, Willassen NP (2000) Cold adapted enzymes. Biotechnol Annu Rev 6:1-57

Struvay C, Feller G (2012) Optimization to low temperature activity in psychrophilic enzymes. Int J Mol Sci 13:11643-11665

Tanaka D, Yoneda S, Yamashiro Y, Sakatoku A, Kayashima T, Yamakawa K, Nakamura S (2012) Characterization of a new coldadapted lipase from Pseudomonas sp TK-3. Appl Biochem Biotechnol 168:327-338

Tecelão C, Silva J, Dubreucq E, Ribeiro MH, Ferreira-Dias S (2010) Production of human milk fat substitutes enriched in omega-3 polyunsaturated fatty acids using immobilized commercial lipases and Candida parapsilosis lipase/acyltransferase. J Mol Catal B: Enzym 65:122-127

Vaysse L, Dubreucq E, Pirat J-L, Galzy P (1997) Fatty hydroxamic acid biosynthesis in aqueous medium in the presence of the lipaseacyltransferase from Candida parapsilosis. J Biotechnol 53:4146

Vaysse L, Ly A, Moulin G, Dubreucq E (2002) Chain-length selectivity of various lipases during hydrolysis, esterification and alcoholysis in biphasic aqueous. Enzym Microb Technol 31:648-655

Villeneuve P (2007) Lipases in lipophilization reactions. Biotechnol Adv 25:515-536

Wang Q, Hou Y, Ding Y, Yan P (2012) Purification and biochemical characterization of a cold-active lipase from Antarctic sea ice bacteria Pseudoalteromonas sp. NJ 70. Mol Biol Rep 39:9233-9238 
Widmann M, Juhl PB, Pleiss J (2010) Structural classification by the Lipase Engineering Database: a case study of Candida antarctica lipase A. BMC Genomics 11:1471-2164

Wolf-Watz M, Thai V, Henzler-Wildman K, Hadjipavlou G, Eisenmesser EZ, Kern D (2004) Linkage between dynamics and catalysis in a thermophilic-mesophilic enzyme pair. Nat Struct Mol Biol 11:945949

Zheng X, Chu X, Zhang W, Wu N, Fan Y (2011) A novel cold-adapted lipase from Acinetobacter sp. XMZ-26: gene cloning and characterisation. Appl Microbiol Biotechnol 90:971-980 